\title{
Nickel Stabilized Zirconia for SOFCs: Synthesis and Characterization
}

\author{
Ezzat S. Els hazly", Omar A. A. Abde lal \\ Metallurgy Department, Nuclear Research Center, Atomic Energy Authority, P.O.Box 13759, Cairo, Egypt
}

\begin{abstract}
Nanocrystalline tetragonal zirconia is commercially very significant material which finds extensive use as an anode material in SOFCs, as a catalyst oxygen sensor and structural material. Nanocrystalline zirconia powders for high performance anode of SOFCs have been synthesized by co-precipitation route. This technique is very helpful for the promotion of the stabilization of tetragonal phase of $\mathrm{ZrO}_{2}$ in nano level at moderate temperature. The main objective of this paper is to stabilize the $\mathrm{t}-\mathrm{ZrO}_{2}$ through precipitation route using $\mathrm{NH}_{4} \mathrm{OH}$ solution. The processing features and the microstructural characteristics of NiO- $\mathrm{ZrO}_{2}$ have been investigated by DSC-TG, XRD, SEM, and IR spectroscopy.The concentration of nickel-salt plays an important role for the enhancement of stabilized tetragonal phase at moderate temperature. From XRD results it was found that the $\mathrm{t}-\mathrm{ZrO}_{2}$ was more stabilized with $20 \mathrm{~mol} \% \mathrm{n}$ ickel-salt concentration compared with $40 \mathrm{~mol} \% \mathrm{Ni}$-salt at the same temperature.
\end{abstract}

Keywo rds Ni stabilized $\mathrm{ZrO}_{2}$, Synthesis, Co-precipitation Route

\section{Introduction}

Solid oxide fuel cells (SOFCs) are environmentally friendly energy conversion systems to produce electrical energy with minimal environmental impact [1-4]. The efficient operation of SOFC anode is strongly depends on its microstructural parameters such as particle size, composition and spatial distributions of the constituent phases. Most present SOFCs developers use yttria-stabilized zirconia (YSZ) as electrolyte, strontium-doped lanthanum manganite (LSM) as cathode and Ni-YSZ ceramic metallic composite (cermet) as supported anode materials [5-7]. Ni-YSZ cermet is an electronic conductive material formed during the SOFC stack operation by the reduction of NiO-YSZ used at the anode site during cell fabrication process. NiO-YSZ is an insulating material and its complete reduction to Ni-YSZ is necessary to assure good anodic performance. Ni-YSZ cermets have been used as SOFC anodes main ly due to their high electronic conduction, good electrochemical performance in the intermediate temperature range $\left(750-850^{\circ} \mathrm{C}\right)$ and high catalytic activity in reform reactions and the comparatively low cost of nickel[7-8]. During the chemical reaction occurs between $\mathrm{NiO}$ and $\mathrm{ZrO}_{2}$, the ionic radius of $\mathrm{Ni}^{+2}$ being relatively s mall co mpared to the size of $\mathrm{ZrO}_{2}$ and this gives rise to a solid-solution of nickel oxide and zirconia. The particle size of nickel oxide has a great

* Corresponding author:

ezzatelshazly@gmail.com (Ezzat S. Elshazly)

Published online at http://journal.sapub.org/ijmee

Copyright (C) 2012 Scientific \& Academic Publishing. All Rights Reserved effect on the stabilization of tetragonal phase of zirconia[9-11]. The formation of the tetragonal solid-solution of $\mathrm{NiO}_{2}-\mathrm{ZrO}_{2}$ is believed to be due to the smallness of grains, hence, the enhanced surface reactivity and diffusion of the atoms at the surface. In general, the stabilization of tetragonal/cubic phase of zirconia has been found to be dependant on many parameters such as ionic size of dopant, valency, electronegitivity etc.[12].

The presence of the tetragonal phase is due to the effect of either the dopant concentration or the grain size of the dopant. The formation of the tetragonal solid solution of $\mathrm{NiO}-\mathrm{ZrO}_{2}$ is believed to be due to the smallness of the grains, hence, the enhanced surface reactivity and diffusion of the ato $\mathrm{ms}$ at the surfaces[13-14]. In general, stabilization of the tetragonal/cubic phase of $\mathrm{ZrO}_{2}$ has been found to be dependent on many parameters such as ionic size of the dopant, valence, and electronegativity[15].

Till today, so many works have been done to obtain the high temperature cubic phase and tetragonal phases in a thermodynamically stable at low temperature using different synthesis techniques like sonochemical, hydrothermal, chemical precipitation and sol-gel etc. In this paper, we are emphasis on the synthesis and stabilization of tetragonal zirconia by varying the Ni-salt concentration. Thermal, structural, microstructure analysis and as well as IR spectroscopy were carried out

\section{Experimental Procedures}

\subsection{Synthesis}


Nano sized particles of Ni stabilized zirconia particles was prepared through co-precipitation technique using $\mathrm{NH} 4 \mathrm{OH}$ solution. An aqueous solution of $1 \mathrm{M}$ (where $\mathrm{M}$ is the molarity) concentration of $\mathrm{Zr}$-salt $\left(\mathrm{ZrOCl}_{2} .8 \mathrm{H}_{2} \mathrm{O}\right)$ were prepared from high purity $\mathrm{Zr}$-salt which is highly acidic in nature (having a $\mathrm{pH}=0.3$ ), while the $\mathrm{pH}$ of $\mathrm{NH} 4 \mathrm{OH}$ solution was found to be 12.83 which is highly basic in nature. $\mathrm{NH}_{4} \mathrm{OH}$ solution was added drop wise to a beaker containing $1 \mathrm{M}(1-\mathrm{x}) \quad \mathrm{mol} \% \mathrm{Zr}$-salt and $1 \mathrm{Mx} \quad \mathrm{mol} \% \quad \mathrm{Ni}$-salt $\left(\mathrm{NiCl}_{2} \cdot 6 \mathrm{H}_{2} \mathrm{O}\right)$ [where $\mathrm{x}=0,20$ and 40 ] solution with constant stirring by a magnetic stirrer. A gel was formed and excess addition of $\mathrm{NH}_{4} \mathrm{OH}$ solution leads to precipitation was allowed to settle out. The precipitate was washed with hot water for several times to remove chlorine from solution. The precipitate was dried at $80^{\circ} \mathrm{C}$ for 24 hours. The obtained dried sample was crushed and grinded to obtain very fine powder. The fine powder was calcined at $700^{\circ} \mathrm{C}, 800^{\circ} \mathrm{C}$ and $900{ }^{\circ} \mathrm{C}$ for 1 hour. The whole preparation process is schematically illustrated in Fig. 1.

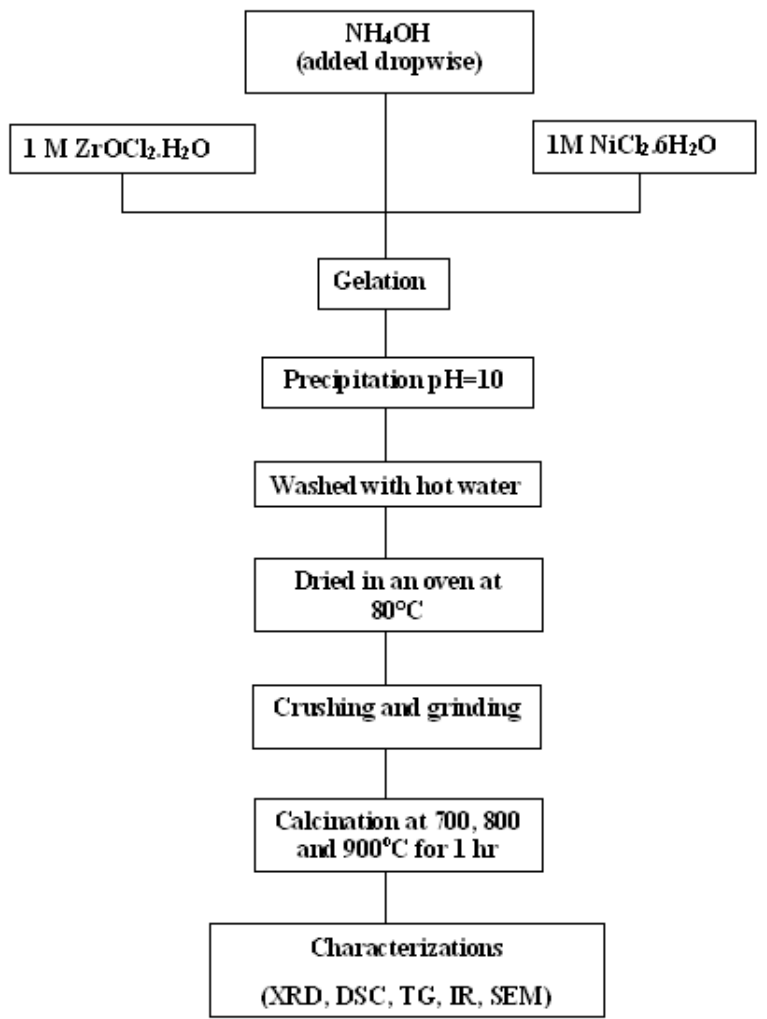

Figure 1. Schematic diagram of the preparation of Ni-doped $\mathrm{ZrO}_{2}$ powder

\subsection{Gener al characterization}

Thermal deco mposition of $\mathrm{ZrO}(\mathrm{OH})_{2}$ gel to an amorphous $\mathrm{ZrO}_{2}$ powder followed by its reconstructive nucleation of $\mathrm{t}-\mathrm{ZrO}_{2}$ nanoparticles were studied using thermogravimetric and differential scanning calorimetric (TG-DSC) by heating the sample at $100^{\circ} \mathrm{C} / \mathrm{min}$ in $\mathrm{N} 2$ atmosphere in a thermal analyser (Netzsch, STA 449C). Alpha alumina was used as reference material. Phase analysis was studied using the room temperature powder X-ray diffraction (PW 1830 Diffractometer, Phillips, Netherland) with filtered $0.154 \mathrm{~nm}$
$\mathrm{Cu} \mathrm{K} \alpha$ radiation. Samples are scanned in a continuous mode from 20o-80o with a scanning rate of $0.04^{\circ} / \mathrm{sec}$. Microstructural features were studied using Scanning Electron Microscope (JSM 6480 LV JEOL, Japan).

Size of the particles is usually obtained with the help of scanning electron microscopy (SEM). The size corresponds to the mean value of the crystalline domain size of the particles is determined from the X-ray line broadening using Debye-Scherrer formula with correction factor as given below,

$$
d \text { †े } \frac{0.9}{\cos }
$$

Where $\beta$ is the angular line width of half maximum intensity, $\mathrm{d}$ is is the crystallite size, $\lambda$ is the $\mathrm{X}$-ray wavelength used, and $\theta$ is the Bragg's angle in degree.

\section{Results and Discussion}

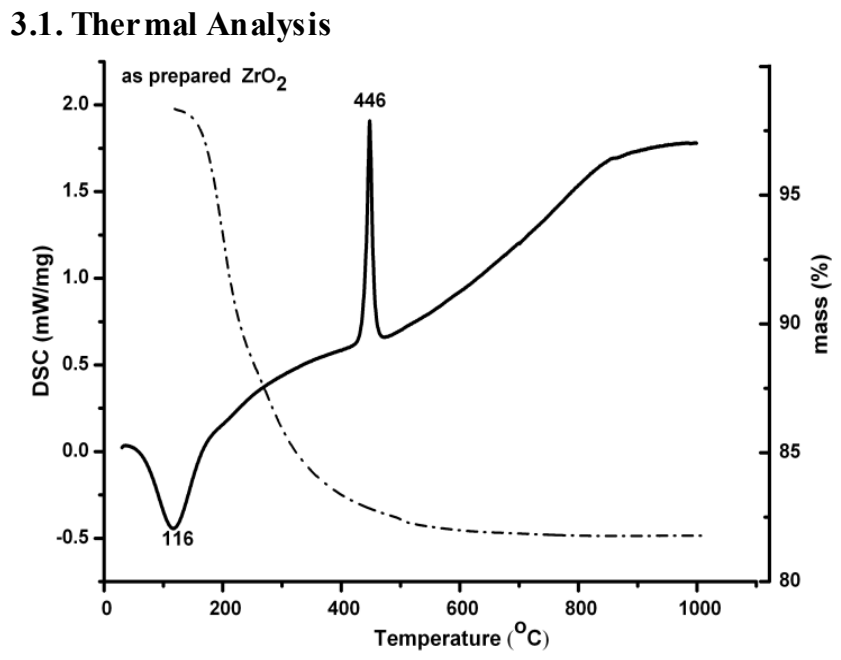

Figure 2. DSC-T Gof pure $\mathrm{ZrO}_{2}$

The thermal behavior of the nanocrystalline $\mathrm{Ni}$ doped $\mathrm{ZrO}_{2}$ powder is studied up to $1000{ }^{\circ} \mathrm{C}$ using $\mathrm{DSC} / \mathrm{TG}$ analys is. It is clearly shown from figure 2 that the as prepared $\mathrm{ZrO}_{2}$ powder exhibits an endothermic peak at a temperature of $116{ }^{\circ} \mathrm{C}$ due to evolution of water absorbed on the as-prepared powder. With increasing temperature, it shows a very sharp exothermic peak at $446^{\circ} \mathrm{C}$ which is related to the fast crystallization into metastable tetragonal Zirconia. To make certain of the structure of the as-synthesized powder, the thermogravimetric analysis (TGA) is conducted. The TGA analysis shows that the weight loss is approximately $31 \%$. The humps in the range of $300-400^{\circ} \mathrm{C}$ indicate the decomposition of Zirconium hydroxide $\mathrm{ZrO}(\mathrm{OH})_{2}$ to $\mathrm{ZrO}_{2}$. Figure 3 shows the DSC-TG graph of $40 \mathrm{~mol} \% \mathrm{Ni}$ doped $\mathrm{ZrO}_{2}$ powder; it has two endothermic peaks at temperature $123^{\circ} \mathrm{C}$ and $329^{\circ} \mathrm{C}$. It may be due to the evaporation of water absorbed by as prepared $40 \mathrm{~mol} \% \mathrm{Ni}$ doped $\mathrm{ZrO}_{2}$. Further increase in temperature shows a sharp exothermic peak at a temperature $630^{\circ} \mathrm{C}$ related to the fast crystallization into metastable tetragonal zirconia. To make certain of the 
structure of the as-synthesized powder, the thermogravimetric analysis (TGA) is conducted.
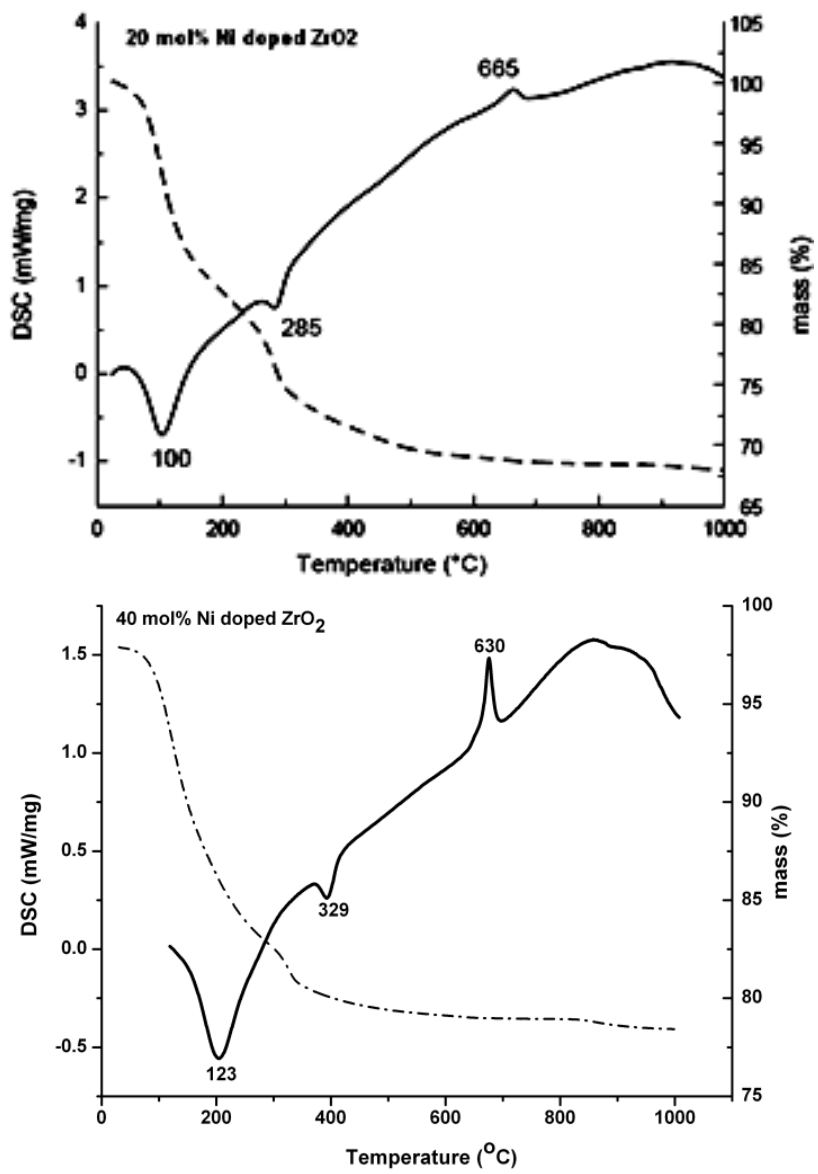

Figure 3. DSC-T G of $20 \mathrm{~mol} \%$, and $40 \mathrm{~mol} \% \mathrm{Ni}$ doped $\mathrm{ZrO}_{2}$

\subsection{X-r ay Diffr action}



Figure 4. $\mathrm{XRD}$ patterns of pure $\mathrm{ZrO}_{2}$ calcined at different temperatures

By co-precipitation technique, $1 \mathrm{M} \quad \mathrm{ZrO}_{2}, \quad 0.2 \mathrm{M}$ $\mathrm{NiO}-0.8 \mathrm{ZrO}_{2}$ and $0.4 \mathrm{M} \mathrm{NiO}-0.6 \mathrm{ZrO}_{2}$ were reacted with $\mathrm{NH}_{4} \mathrm{OH}$ by maintaining a final $\mathrm{pH}$ to be $\sim 10$. Fig. 4 shows the $\mathrm{XRD}$ patterns of the synthesized $\mathrm{ZrO}_{2}$ nanopowder calcined at three different temperatures, 700,800 , and $900^{\circ} \mathrm{C}$. Fig. 5 shows the XRD patterns of the synyhesized $\mathrm{ZrO}_{2}$ nanopowder doped with $20 \mathrm{~mol} \% \mathrm{Ni}$ and calcined at three different temperatures, 700,800 , and $900^{\circ} \mathrm{C}$. Fig. 6 shows the XRD patterns of the synyhesized $\mathrm{ZrO}_{2}$ nanopowder doped with $40 \mathrm{~mol} \% \mathrm{Ni}$ and calc ined at three different temperatures, 700,800 , and $900^{\circ} \mathrm{C}$.

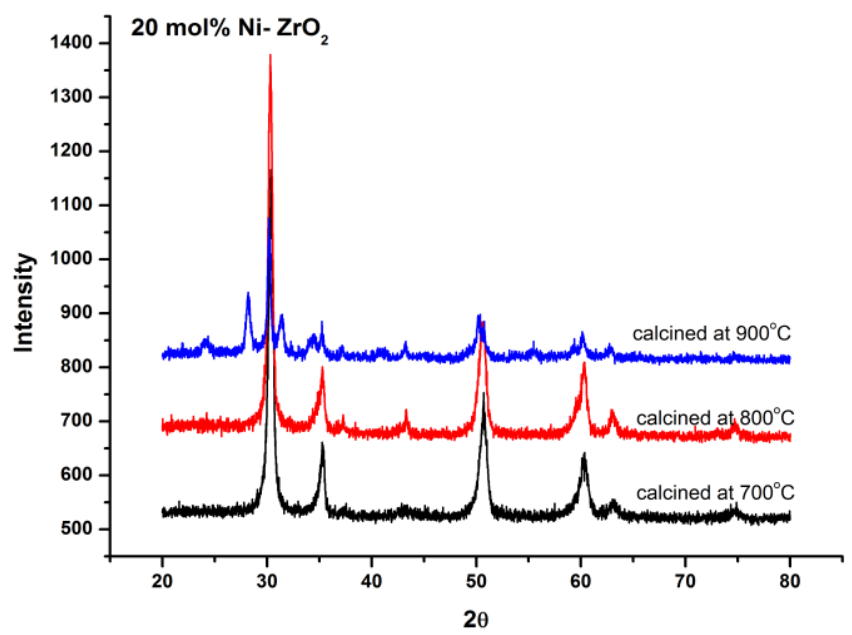

Figure 5. XRD patterns of $20 \mathrm{~mol} \% \mathrm{Ni}$ doped $\mathrm{ZrO}_{2}$ calcined at different temperatures

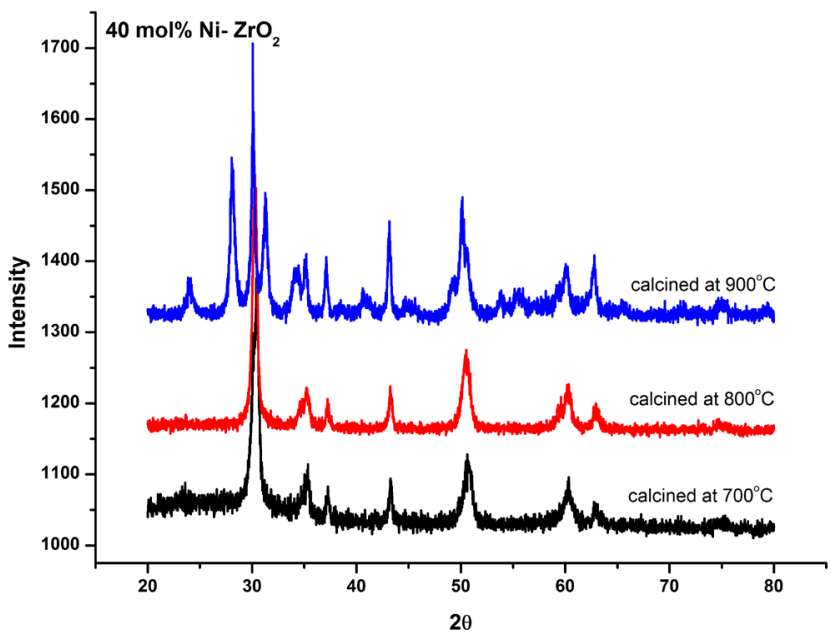

Figure 6. XRD patterns of $40 \mathrm{~mol} \% \mathrm{Ni}$ doped $\mathrm{ZrO}_{2}$ calcined at different temperatures

At $700^{\circ} \mathrm{C}$ calcination temperature, it is quite clear that the presence of monoclinic phase in pure zirconia powder is dominant. The crystallite $\mathrm{NiO}$ peaks were observed as a second phase at $2 \theta=36.83^{\circ}, 42.88^{\circ}$, and $62.52^{\circ}$. From XRD pattern, it is clearly shown that the monoclinic phase in as prepared zirconia powder is dominant. With the addition of $20 \mathrm{~mol} \%$ of nickel, the monoclin ic phase was suppressed and the tetragonal phase was enhanced. Development of $\mathrm{NiO}$ along with $\mathrm{t}-\mathrm{ZrO}_{2}$ was observed for $40 \mathrm{~mol} \% \mathrm{Ni}$ doped $\mathrm{ZrO}_{2}$ powders. The crystallite size of pure zirconia, $20 \mathrm{~mol} \%$ and $40 \mathrm{~mol} \%$ nickel doped $\mathrm{ZrO}_{2}$ was calculated using scherrer's formula and was found to be $46.3 \mathrm{~nm}, 27.8 \mathrm{~nm}$, and $139.5 \mathrm{~nm}$ respectively. 
At $800^{\circ} \mathrm{C}$ calcination temperature, it is quite clear that in pure zirconia powder the presence of monoclinic phase is dominant. W ith $20 \mathrm{~mol} \%$ addition of nickel, the monoclin ic phase was suppressed and the tetragonal phase has been enhanced. Further addition of $\mathrm{Ni}$, i.e. $40 \mathrm{~mol} \%$, leads to development of $\mathrm{NiO}$ a long with $\mathrm{t}-\mathrm{ZrO}_{2}$. By using scherrer's formula, the crystallite size of pure zirconia, $20 \mathrm{~mol} \%$, and $40 \mathrm{~mol} \%$ nickel doped $\mathrm{ZrO}_{2}$ was calculated and found to be $24.4 \mathrm{~nm}, 27.8 \mathrm{~nm}$ and $22 \mathrm{~nm}$ respectively.

While at $900^{\circ} \mathrm{C}$ calcination temperature and by analyzing the XRD pattern it was found that in case of pure zirconia powder the major phase is monoclinic with minor amount of tetragonal phase ( $\sim 99 \%$ monoclic and $\sim 1 \%$ tetragonal). At $20 \mathrm{~mol} \% \mathrm{Ni}$ addition the monoclinic phase suppressed to 40 vol $\%$ and tetragonal phase developed to $\sim 60$ vol $\%$ with presence of minor amount of $\mathrm{NiO}$ phase $(\sim 5 \mathrm{vol} \%)$. Further addition of nickel concentration leads to a decrease in tetragonal phase and an increase in monoclinic as well increase of $\mathrm{NiO}$ phase. This may be explained as follows: the increased concentration of dopant $\mathrm{NiO}$ helps nucleation of crystallites and enhances grain growth, the grain size was found to be larger in $40 \mathrm{~mol} \%$ compared to other composition of powders. Higher grain size is inversely propotional to surface area so reduced reactivity. Crystallite size of pure zirconia, $20 \mathrm{~mol} \%$ and $40 \mathrm{~mol} \%$ nickel doped $\mathrm{ZrO}_{2}$ were calculated using scherrer's formula and found to be $37.7 \mathrm{~nm}, 37.9 \mathrm{~nm}$ and $59.6 \mathrm{~nm}$ respectively.

Here we may conclude that at higher concentration of $\mathrm{Ni}$ in $\mathrm{Ni}-\mathrm{ZrO}_{2}$ composite which is calcined at high temperature, tetragonal phase of $\mathrm{ZrO}_{2}$ is completely stabilized and it also shows the effect of $\mathrm{NiO}$ prominently. So, this is the perfect condition of the sample which is liable for practical application.

\subsection{IR spectros copy}

Infra-Red spectra in the range of $500-4000 \mathrm{~cm}-1$ for the as-prepared $\mathrm{ZrO}_{2}$ as well as the Ni doped $\mathrm{ZrO}_{2}$ powders with different concentrations were observed. Figure 7 shows the typical IR spectra of both the as-prepared $\mathrm{ZrO}_{2}$ and that calcined at $800^{\circ} \mathrm{C}$. On the other hand, figure 8 shows the IR spectra of both the as-prepared $20 \mathrm{~mol} \% \mathrm{Ni}$ doped $\mathrm{ZrO}_{2}$ and that calcined at $800^{\circ} \mathrm{C}$.

From the IR spectras, it is clearly shown that the as-prepared powders reveal that the $\mathrm{ZrO}_{2}$ nano powders have a significant amount of surface-adsorbed $\mathrm{H}_{2} \mathrm{O}$ molecules has been assigned at 340 land $3446 \mathrm{~cm}^{-1}$ for the as prepared and the calcined $\mathrm{ZrO}_{2}$ respectively. While the as-prepared $\mathrm{ZrO}_{2}$ as well as $\mathrm{Ni}$ doped $\mathrm{ZrO}_{2}$ that calcined at $800^{\circ} \mathrm{C}$ shows $\mathrm{Zr}-\mathrm{O}$ vibration as observed at 740 and $680 \mathrm{~cm}^{-1}$.

The size, shape and agglomeration behaviour of $\mathrm{Ni}$ doped $\mathrm{ZrO}_{2}$ was obtained by using scanning electron microscopy (SEM). Fig. 9 (a), (b) and (c) show the mic rostructural SEM secondary and backscattered images of the as prepared $\mathrm{ZrO}_{2}$, $20 \mathrm{~mol} \% \mathrm{Ni}$ doped $\mathrm{ZrO}_{2}$, and $40 \mathrm{~mol} \% \mathrm{Ni}$ doped $\mathrm{ZrO}_{2}$ powder respectively. The partic le size was found to be nearly spherical and agglomerate in nature.
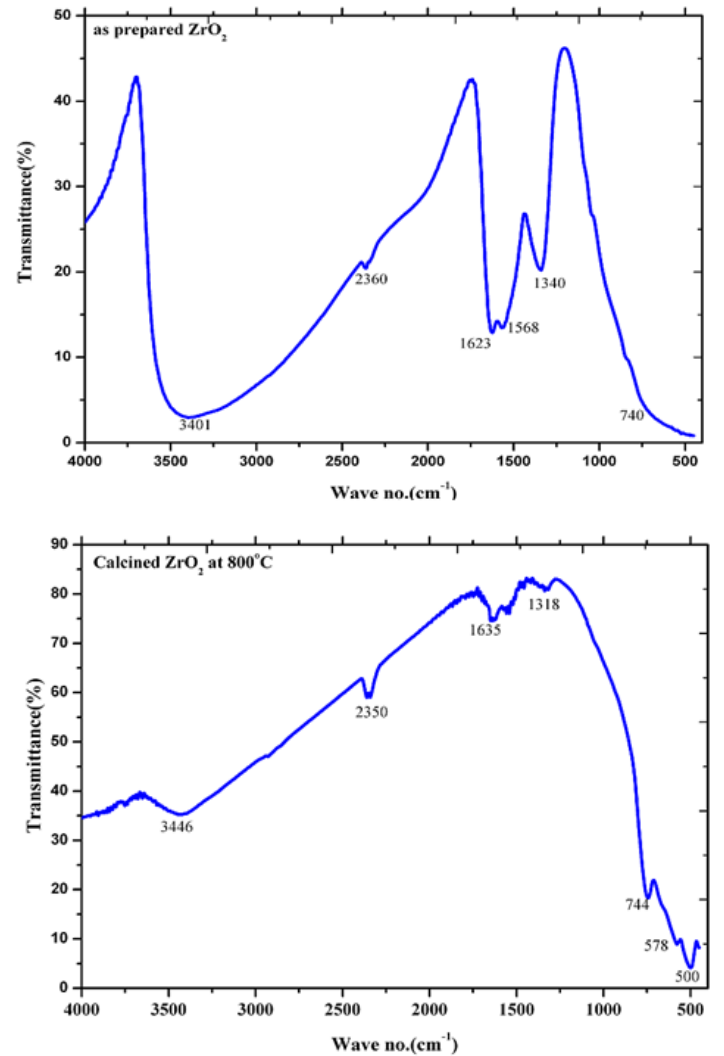

Figure 7. IR spectra of as-prepared $\mathrm{ZrO}_{2}$ and calcined $\mathrm{ZrO}_{2}$ at $800^{\circ} \mathrm{C}$
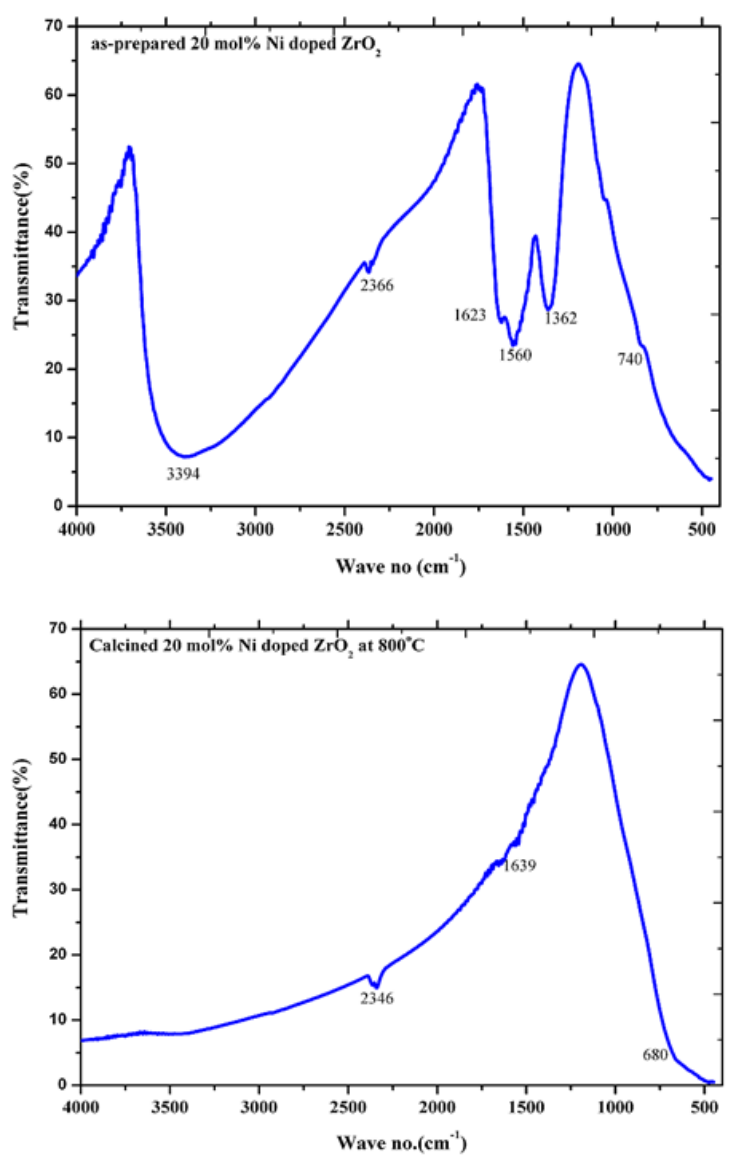

Figure 8. IR spectra of as-prepared $20 \mathrm{~mol} \% \mathrm{Ni}$ doped $\mathrm{ZrO} 2$ and calcined $20 \mathrm{~mol} \% \mathrm{Ni}$ doped $\mathrm{ZrO}_{2}$ at $800^{\circ} \mathrm{C}$ 

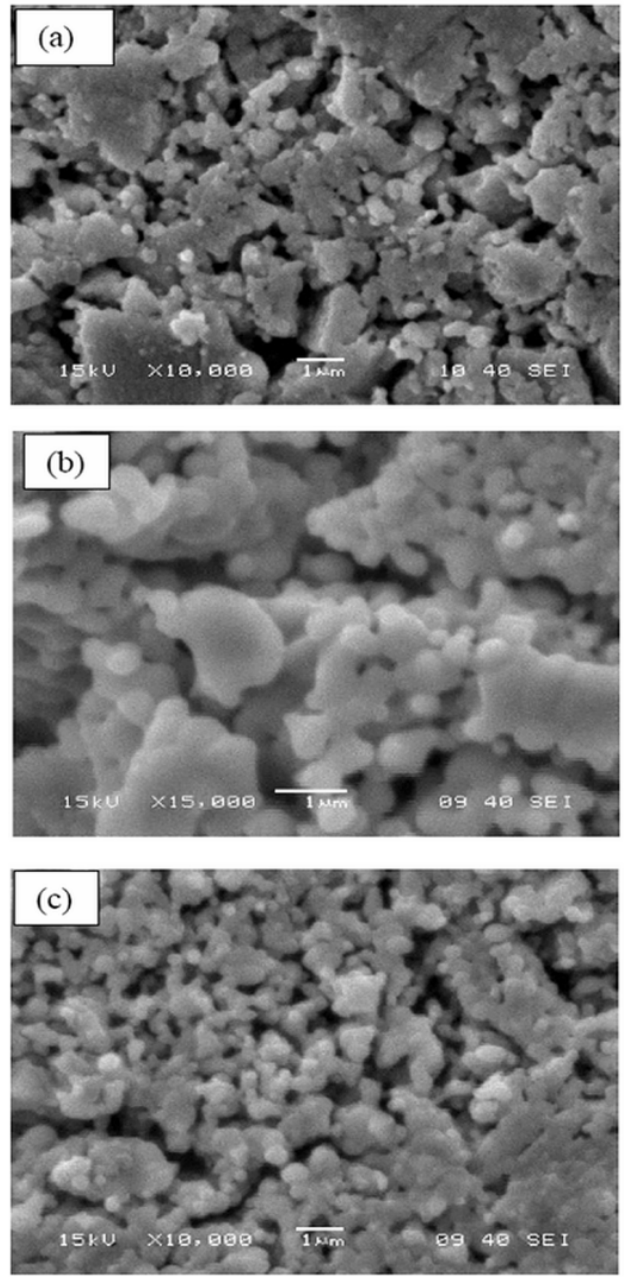

Figure 9. SEM images of (a) $\mathrm{ZrO}_{2}$, (b) $20 \mathrm{~mol} \% \mathrm{Ni}$ doped $\mathrm{ZrO}_{2}$, and (c) $40 \mathrm{~mol} \% \mathrm{Ni}$ doped $\mathrm{ZrO}_{2}$

\section{Conclusions}

Co-precipitation route using $\mathrm{NH}_{4} \mathrm{OH}$ has been successfully emp loyed to synthes is nonocrystalline $\mathrm{Ni}-\mathrm{ZrO}_{2}$ powder for SOFCs. Characterization by X-ray diffraction and IR spectroscopy confirmed the presence of nanocrystallite phases of $\mathrm{NiO}$ and $\mathrm{ZrO}_{2}$. Stabilization of metastable $\mathrm{t}-\mathrm{ZrO}_{2}$ is observed at $20 \mathrm{~mol} \%$ of nickel salt at a calcination temperature of $800^{\circ} \mathrm{C}$. From XRD results it has been concluded that small crystallites $(27.8 \mathrm{~nm})$ stabilizes metastable $\mathrm{t}-\mathrm{ZrO} \mathrm{r}_{2}$ at intermediate temperature range. Due to the presence of lattice strain above a certain concentration of nickel salt, there is decrease in tetragonal phase.

\section{REFERENCES}

[1] A. Chandra Bose, R. Ramamoorthy, S. Ramasamy, "Formability of metastable tetragonal solid solution in nanocrystalline $\mathrm{NiO}-\mathrm{ZrO} 2$ powders", Materials Letters, vol 44, pp.203-207, 2000.

[2] S. Li, R. Guo, J. Li, Y. Chen, W. Liu, "Synthesis of NiO-ZrO2 powders for solid oxide fuel cells", Ceramics International, vol. 29, pp.883-886, 2003.

[3] H. Kondo, T. Sekino, T. Kusunose, T.C. Nakayam, Y. Yamamoto, K. Niihara, "Phase Stability And Electrical Property Of Nio-doped Yttria Stabilized Zirconia", Materials Letters, vol.57, pp.1624-1628, 2003.

[4] S. Shukla, S. Seal, R. Vij, S. Bandyopadhyay, Z. Rahman, "Effect of Nanocrystallite Morphology on the Metastable Tetragonal Phase Stabilization In Zirconia", Nano Letters, vol.2, no.9, pp.989-993, 2002.

[5] R. Srinivasan, L. Rice, B. H. Dav is, "Critical paricle size and phase Transformation in Zirconia: Transmission Electron Microscopy and X-ray", Journal of The American Ceramic Society, vol.73, pp.3528, 1990.

[6] N.L. Wu and T. F. Wu, "Enhanced phase stability for tetragonal Zirconia in precipitation Synthesis", Journal of American Ceramic Society, vol.83,pp. 3225-3227, 2000.

[7] W.E. Lee, W. Mark Rainforth, "Ceramic Microstructure: Property Control by Processing", Chapman \&Hall, 1994.

[8] M.K. Dongare, K. Malshe, C.S. Gopinath, I.K. Murwani, E. Kemnitz, "Oxidation activity and 180-isotope exchange behavior of nickel oxide-stabilized cubic zirconia", Journal of Catalysis, vol.222,pp.80-86, 2004.

[9] N.Q. Minh, T. Takahashi, "Science and Technology of Ceramic Fuel Cells", Nagoya, Japan, 1994.

[10] C. Tongxiang, Z. Yanwei, Z. Wei, G. Cuijing, Y. Xiaowei, "Synthesis of nanocomposite nickel oxide/yttrium-stabilized zirconia (NiO/YSZ) powders for anodes of solid oxide fuel cells (SOFCs) via microwave-assisted complex-gel auto-combustion", Journal of Power Sources, vol.195, pp.1308-1315, 2010.

[11] W.K.Yoshito, M.A.Scapin, V.Ussui, D.R.R.Lazar, J.O.A. Paschoal, "Combustion Synthesis of NiO/YSZ Composite", Materials Science Forum. vol. 591-593, pp.777-783, 2008

[12] T.Talebi, M.H.Sarrafi, M.Haji, B.Raissi, A. Maghsoudipour, "Investigation on microstructures of NiO-YSZ composite and Ni-YSZ cermet for SOFCs. International journal of hy drogen energy", vol. 35, pp.9440-9447, 2010.

[13] K.Sato, G.Okamoto, M.Naito, H. Abe,'NiO/YSZ nanocomposite particles synthesized via co-precipitation method for electrochemically active Ni/YSZ anode", Journal of Power Sources. 193: 185-188, 2009.

[14] H.Shimada, E.Takami, K.Takizawa, A. Hagiwara, M.Ihara, "Highly dispersed anodes for solid oxide fuel cells using $\mathrm{NiO} / \mathrm{YSZ} / \mathrm{BZY}$ triple-phase composite powders prepared by spray pyrolysis", Solid State Ionics, vol. 193, pp.43-51, 2011.

[15] R.M.C.Clemmer, S.F.Corbin,'Investigating the Sintering Behavior of Porous Composites Made from Metallic Ni and YSZ Powders", International Journal of Applied Ceramic Technology, vol.8, no.4, pp. 895-904, 2011. 